\title{
Effects of controlled and pressure support mechanical ventilation on rat diaphragm muscle $^{1}$
}

\author{
Efeitos da ventilação mecânica controlada e por pressão de suporte no músculo diafragma de \\ ratos
}

\author{
André de Sá Braga OliveiraI, Lívia Bandeira Costa ${ }^{\mathrm{II}}$, Thiago de Oliveira Assis ${ }^{\mathrm{III}}$, Diógenes Luís da Mota ${ }^{\mathrm{IV}}$, Eduardo Ériko \\ Tenório de Françav, José Cândido de Araújo Filhovi, Silvania Tavares Paz Rosas ${ }^{\mathrm{VII}}$, Paloma Lys de Medeiros ${ }^{\mathrm{VIII}}$
}

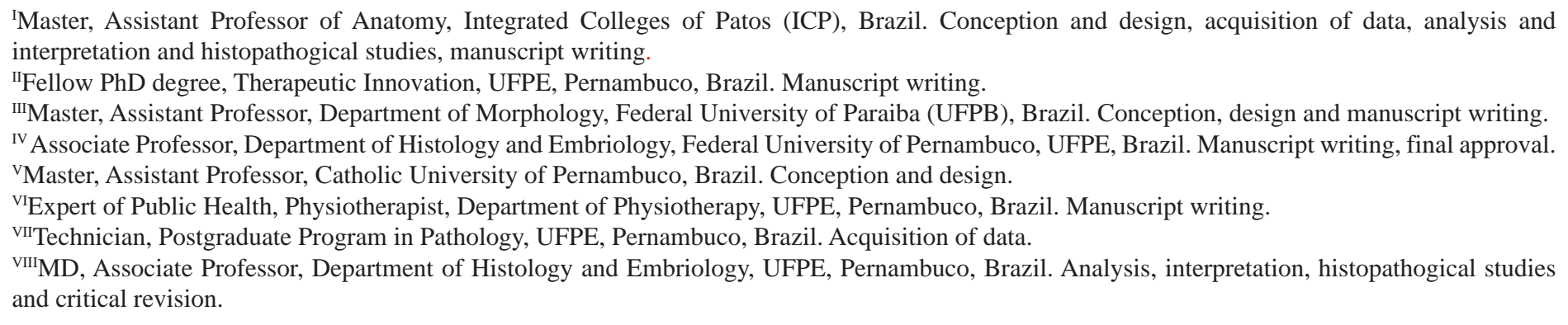

\section{ABSTRACT}

PURPOSE: The objective of this study was to analyze the effects of Pressure Controlled Ventilation mode (PCV-C) and PSV mode in diaphragm muscle of rats.

METHODS: Wistar rats $(n=18)$ were randomly assigned to the control group or to receive 6 hours of PCV and PSV. After this period, animals were euthanized and their diaphragms were excised, frozen in liquid nitrogen and stored in at $-80^{\circ} \mathrm{C}$ for further histomorphometric analysis.

RESULTS: Results showed a 15\% decrease in cross-sectional area of muscle fibers on the PCV-C group when compared to the control group $(\mathrm{p}<0.001)$ and by $10 \%$ when compared to the PSV group $(\mathrm{p}<0.05)$. Minor diameter was decreased in PCV-C group by $9 \%$ when compared with the control group $(\mathrm{p}<0.001)$ and by $6 \%$ when compared to the PSV group $(\mathrm{p}<0.05)$. When myonuclear area was analyzed, a $16 \%$ decrease was observed in the PCV-C group when compared to the PSV group ( $<<0.05)$. No significant difference between the groups was observed in myonuclear perimeter ( $\mathrm{p}>0.05)$.

CONCLUSION: Short-term controlled mechanical ventilation seems to lead to muscular atrophy in diaphragm fibers. The PSV mode may attenuate the effects of VIDD.

Key words: Anatomy \& Histology. Diaphragm. Tracheostomy. Rats, Wistar.

\section{RESUMO}

OBJETIVO: Avaliar os efeitos do modo ventilatório controlado por pressão controlada (PCV-C) e do modo PSV sobre o músculo diafragma de ratos.

MÉTODOS: Ratos $(n=18)$ da linhagem Wistar foram distribuídos no grupo controle (RE) ou para receber AVM por 6 horas no modo PCV-C e no modo PSV. Após esse período, os animais foram eutanasiados, o diafragma retirado e encaminhado para a análise histológica e morfométrica. RESULTADOS: Os resultados revelaram uma redução da área das fibras musculares de 15\% no grupo PCV-C em comparação ao controle $(\mathrm{p}<0,001)$ e de $10 \%$ quando comparado ao grupo PSV ( $<<0,05)$. Já com relação ao diâmetro menor observou-se uma redução de $9 \%$ do grupo PCV-C em comparação ao controle $(\mathrm{p}<0,001)$ e de $6 \%$ em relação ao grupo PSV (p<0,05). Quando avaliada a área dos mionúcleos, notou-se uma redução de 16\% desse parâmetro no grupo PCV-C, comparado ao PSV (p<0,05). Não houve diferença significativa no perímetro dos mionúcleos entre os grupos estudados (p>0,05).

CONCLUSÃO: O grupo PCV-C apresentou atrofia muscular em um período curto de ventilação mecânica. O modo PSV parece atenuar os efeitos da DDIV.

Descritores: Anatomia \& Histologia. Diafragma. Traqueostomia. Ratos Wistar. 


\section{Introduction}

Ventilator-induced diaphragmatic dysfunction (VIDD) is characterized by a reduction in diaphragm force generation capacity due to controlled mechanical ventilation (CMV) and was recently shown to occur in humans ${ }^{1}$, being well-recognized in animal models as well, like rats ${ }^{2,3}$, rabbits ${ }^{4}$, piglets ${ }^{5}$, and baboons ${ }^{6}$. In rats, VIDD develops rapidly, as early as 12 hours after the institution of $\mathrm{CMV}^{7}$.

This dysfunction has been implicated in weaning failure $^{8,9}$. Although weaning failure may be due to numerous factors, VIDD probably plays an important role.

Currently, underlying mechanisms responsible for such phenomenon have not been fully elucidated. Studies demonstrated the following alterations in the diaphragm after controlled mechanical ventilation: reduced muscle mass ${ }^{2,10,11}$; diminished type I, IIa, and IIx/b fiber dimensions ${ }^{3,12,13}$; myofibrillar damage ; $^{4}$ enhanced proteolysis ${ }^{12}$; increased protein oxidation and lipid peroxidation ${ }^{14}$; reduced expression of the insulin-like growth factor (IGF-I) ${ }^{3}$; decreased sarcoplasmic/endoplasmic reticulum $\mathrm{Ca}^{2+}$-ATPase (SERCA-1a) expression ${ }^{15}$; increased expression of muscle atrophy factor (MAF-box) ${ }^{16}$; and a decrease in myonuclear content ${ }^{17}$. All of these factors seem to contribute to the development of VIDD, but the precise contribution of each factor and their apparition kinetics has yet to be defined.

Muscle atrophy and myonuclear loss are important factors in the development of VIDD. The decreased volume of the cytoplasm (atrophy) was observed in the presence of decreased number of myonuclei, although the myonuclear domain (the concept that each myonucleus controls the gene products in a finite volume of a muscle fiber ${ }^{17}$ ) remained constant. This decrease in myonuclear content was mediated by caspase-3-dependent increased apoptosis, which was evident as early as 6 hours after the onset of $\mathrm{CMV}^{7}$. Both the apoptosis and the atrophy were attenuated by the inhibition of caspase- $3^{7}$.

Although CMV can be too harmful to diaphragm muscle fibers, few studies have been developed aiming VIDD prevention $^{16,18,19}$. Maybe diaphragmatic dysfunction could be decreased by spontaneous breathing. Pressure support ventilation has already proved to be efficient in patients with chronic obstructive pulmonary disease and acute respiratory failure ${ }^{20-22}$. We hypothesized that CMV would reduce morphometric parameters of muscle fibers and myonuclei, and PSV, which preserves respiratory muscle activity, would induce less diaphragmatic atrophy.

\section{Methods}

This study was performed in accordance with the recommendations of Brazilian College of Animal Experimentation (COBEA) and Animal Care Committee of Federal University of Pernambuco (Protocol number 23076.012736/2008-16).

Eighteen Wistar rats (approximately 320g) were individually housed and fed rat chow and water ad libitum and were maintained on a 12-hour light-dark cycle for one week before initiation of these experiments. Animals were assigned to 6 hours of spontaneous breathing (SB) or mechanical ventilation on the PCV-C or the PSV mode with $21 \% \mathrm{O}_{2}$ (Figure 1). All surgical procedures were performed using aseptic techniques. After reaching a surgical plane of anesthesia (sodium thiopental, 20 $\mathrm{mg} / \mathrm{kg}$ of body weight, intraperitoneal) and sedation (diazepam, $5 \mathrm{mg} / \mathrm{kg}$ body weight, intraperitoneal), animals were weighed and tracheostomized. Body temperature was monitored (rectal thermometer) and maintained at $37^{\circ} \mathrm{C} \pm 1^{\circ} \mathrm{C}$ with a recirculating heating blanket. Continuing care during the experimental period included expressing the bladder, eyes lubrification and passive movements of the limbs. Airway pressure, tidal volume and flow signals were monitored by the ventilator display. To prevent atelectasis, lungs in the PCV-C and PSV groups were inflated in a tidal volume of $15 \mathrm{~mL} / \mathrm{kg}$ for five consecutive breathings for 15 min during the 6 hours of experiment.



FIGURE 1 - Schematic illustration of the experimental design used. All groups were assigned for 6 hours of SB or MV on PCV-C or PSV modes.

Protocol for controlled mechanical ventilation group $(P C V-C)$

After surgical procedures, animals were mechanically ventilated using a pressure-driven ventilator (Inter 5 Plus Ventilator, Intermed, KESA, Pernambuco, Brazil) in PCV (Pressure-Controlled Ventilation) mode for 6 hours. The tidal 
volume was $10 \mathrm{~mL} / \mathrm{kg}$ body weight and the respiratory rate was 80 breaths per minute, with a fraction of inspired oxygen $\left(\mathrm{FiO}_{2}\right)$ of $21 \%$, and positive end-expiratory pressure of $5 \mathrm{cmH}_{2} \mathrm{O}$. These ventilator conditions resulted in complete diaphragmatic inactivity and prevented noxious effects of hypercapnia on the muscular contractile properties ${ }^{4,10,12}$. At the end of 6 hours, each animal was weighed, and the right costal diaphragm was rapidly removed, dissected and frozen in liquid nitrogen at $-180^{\circ} \mathrm{C}$. Samples were stored at $-80^{\circ} \mathrm{C}$ in a freezer until histological and morphometric analysis.

\section{Protocol for pressure support ventilation group (PSV)}

After surgical procedures, animals were mechanically ventilated using a pressure-driven ventilator (Inter 5 Plus Ventilator, Intermed, KESA, Pernambuco, Brazil) in PSV mode for 6 hours. The level of pressure support applied, determined during preliminary studies, allowed a minute volume of approximately $245 \mathrm{~mL} /$ minute (respiratory rate of approximately 70 breaths per minute and $\mathrm{FiO} 2=21 \%$ ). The range of pressure support level used was $5-8 \mathrm{cmH}_{2} \mathrm{O}$. The ventilator had a flow trigger. The expiratory trigger was $25 \%$ of peak inspiratory flow, and the maximum inspiratory time was set at 1 second. The ventilator had a backup ventilation, but it was not used during the experiments. If the animal was not triggering, no pressure was released. Continuing care during the experiment was also applied as above. At the end of 6 hours, each animal was weighed, and the right costal diaphragm was rapidly removed, dissected and frozen in liquid nitrogen at $-180^{\circ} \mathrm{C}$. Samples were stored at $-80^{\circ} \mathrm{C}$ for further histological and morphometric analysis.

\section{Protocol for spontaneous breathing group (SB)}

Control animals (SB) were free of mechanical ventilation intervention. These animals were submitted to the drugs mentioned above, tracheostomized, and were maintained with continuing care as the other groups until the end of the experimental period (6 hours). Then, their diaphragms were rapidly removed, dissected and frozen in liquid nitrogen at $-180^{\circ} \mathrm{C}$. The samples were stored at $-80^{\circ} \mathrm{C}$ until subsequent assay.

\section{Histological and histomorphometric analysis}

After six hours of mechanical ventilation in the PCV-C and the PSV group, and spontaneous breathing in the SB group, all animals were sacrificed with large hemorrhage by abdominal aortic and inferior vena cava section. Right costal diaphragm was removed, dissected and weighed. Samples were fixed to a cork holder with their fibers oriented perpendicularly to the surface, rapidly frozen in liquid nitrogen and stored at $-80^{\circ} \mathrm{C}$. Serial cross-sections parallel to the cork were done $(10 \mu \mathrm{m})$ with cryostat (Leica, modelo CM 1100, Leica Microsystems Nussloch $\mathrm{GmbH}$, Germany) at $-23^{\circ} \mathrm{C}$ and stained with hematoxylin and eosin. Qualitative examination of these slides was performed by an expert who was not aware of the experimental design of the study. Quantitative examination was realized by computadorized semiautomatic system and Image-lab 2000 software. The parameters evaluated were area and minor diameter of the muscle fibers and area and perimeter of the myonuclei.

\section{Statistical analysis}

Quantitative variables were expressed in mean \pm standard deviation. Kolmogorov-Smirnov test was applied to verify normality. Differences between the PCV-C, PSV and SB groups were tested by one-way analysis of variance (if normal), with post hoc application (Tukey) of the least significant difference test. If not normal, Mann-Whitney test was used. Statistical significance was defined a priori as a $P$ value of less than 0.05 .

\section{Results}

\section{General findings}

No significant difference between initial body weight and final body weight in the studied groups was observed (Table 1), indicating adequate hydration and nutrition during experimental period. The doses of anesthetics and sedatives were similar between groups. Only one death occurred in this study, in the PCV-C group.

TABLE 1 - Body weight of PCV - C, PSV and SB groups.

\begin{tabular}{lccc}
\hline & PCV & PSV & SB \\
\hline Initial body weight, $\mathbf{g}$ & $312.33 \pm 10.5$ & $336.83 \pm 8.4$ & $335.33 \pm 9.1$ \\
Final body weight, $\mathbf{g}$ & $310.11 \pm 11.8$ & $335.45 \pm 6.5$ & $334.33 \pm 7.7$
\end{tabular}

Values expressed in mean \pm standard deviation

Definition of abbreviations: PCV $-\mathrm{C}=$ Pressure controlled ventilation (controlled mechanical ventilation); PSV = Pressure Support Ventilation; $\mathrm{SB}=$ Spontaneous Breathing

\section{Histological analysis}

Qualitative examination of the diaphragm sections stained with hematoxylin and eosin did not reveal any abnormalities in diaphragm histology (Figures 2 and 3). Some muscle fibers did not show myonuclei. It happened because of section plane used. 


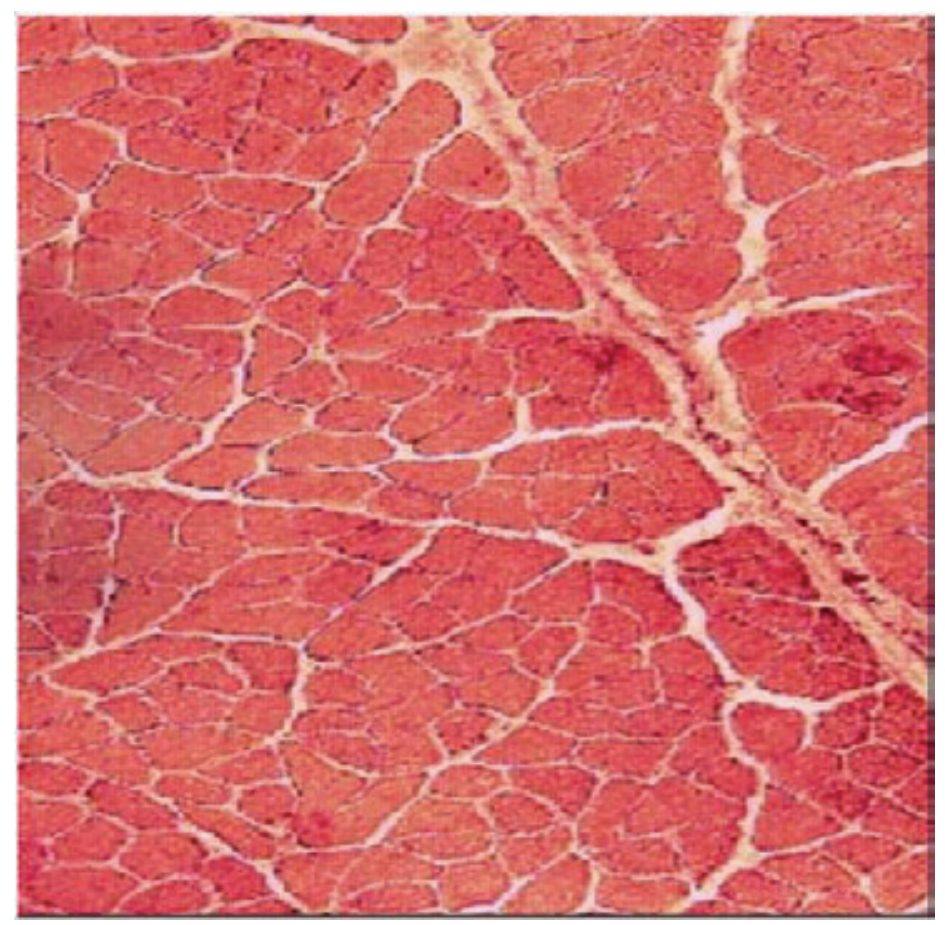

FIGURE 2 - Photomicrography of right diaphragm muscle of a rat in PSV mode. We observe muscle fascicles. HE staining. 100X.

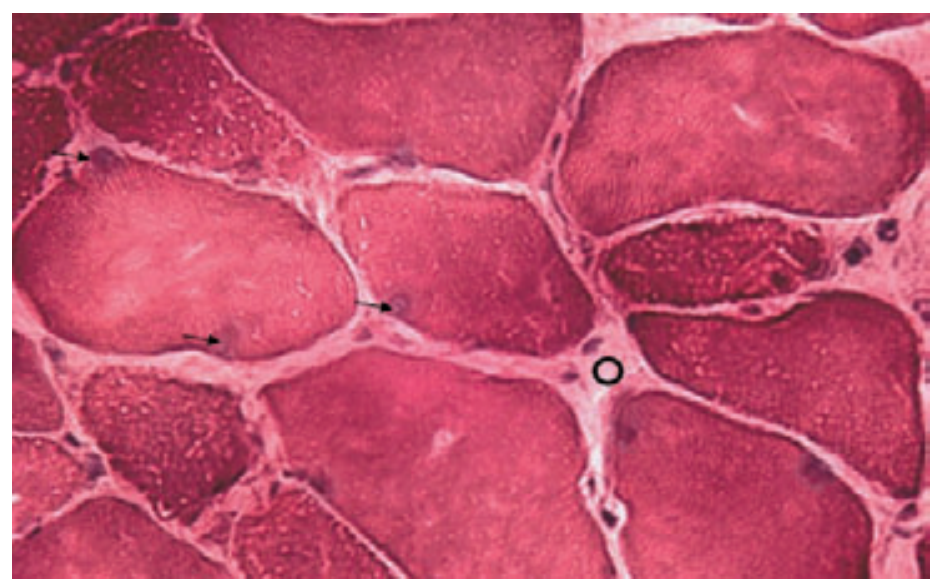

FIGURE 3 - Photomicrography of right diaphragm muscle of a rat in PSV mode. We observe multinucleated cells with peripheral localization (black arrows). The endomysium connective tissue is observed among muscle fibers (open circle). HE staining. 400X.

\section{Area and minor diameter of muscle fibers}

We found a significant decrease $(\mathrm{p}<0.001)$ of muscle fibers area in the PCV-C group $\left(407.70 \mu \mathrm{m}^{2} \pm 198.59 \mu \mathrm{m}^{2}\right)$ when compared with the SB group $\left(480.75 \mu \mathrm{m}^{2} \pm 246.54 \mu \mathrm{m}^{2}\right)$ and the PSV group $\left(453.43 \mu \mathrm{m}^{2} \pm 215.97 \mu \mathrm{m}^{2}\right)$, with $\mathrm{p}=0.003$ (Figure 4).

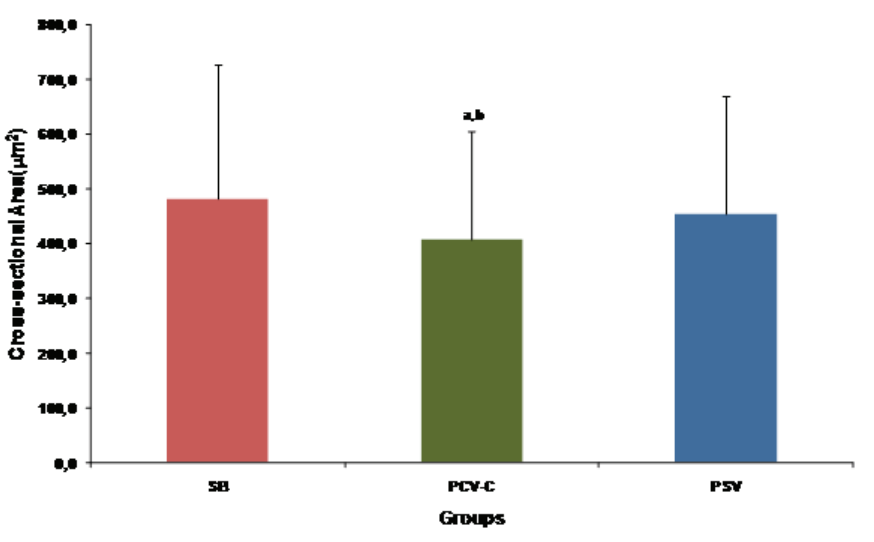

FIGURE 4 - Effects of controlled mechanical ventilation (PCV-C) and Pressure Support Ventilation (PSV) on rat diaphragm muscle fibers area. We observe muscle atrophy in the PCV-C group when compared to the control group (SB) and to the PSV group. Values are represented as mean \pm standard deviation. $\mathbf{a}(\mathrm{p}<0.001)$ indicates difference between the PCV-C and the SB groups; $\mathbf{b}(\mathrm{p}<0.05)$ indicates difference between the PCV-C and the PSV groups (Mann-Whitney test).

When we analyzed minor diameter of muscle fibers, we found similar results: the PCV-C group $(18.70 \mu \mathrm{m} \pm 5.13 \mu \mathrm{m})$ had a significant reduction $(\mathrm{p}<0.001)$ in minor diameter when compared to the SB group $(20.43 \mu \mathrm{m} \pm 5.49 \mu \mathrm{m})$, and to the PSV group $(19.89 \mu \mathrm{m} \pm 5.32 \mu \mathrm{m})$, with $\mathrm{p}=0.002$ (Figure 5).

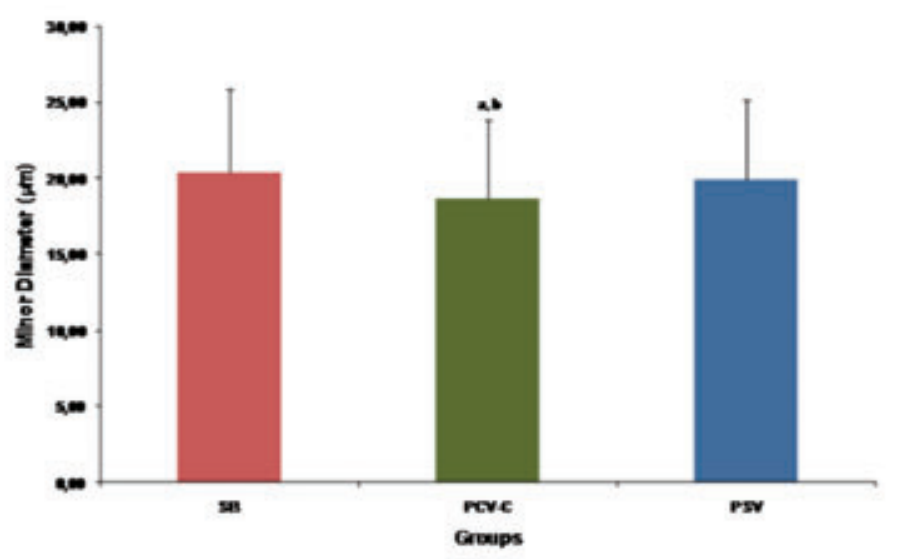

FIGURE 5 - Effects of controlled mechanical ventilation (PCV-C) and Pressure Support Ventilation (PSV) in rat diaphragm muscle fibers minor diameter. We observe muscle atrophy in the PCV-C group when compared to the control group (SB) and to the PSV group. Values are represented as mean \pm standard deviation. $\mathbf{a}(\mathrm{p}<0.001)$ indicates difference between PCV-C and SB groups; $\mathbf{b}(\mathrm{p}<0.05)$ indicates difference between PCV-C and PSV groups (Mann-Whitney test).

\section{Area and perimeter of myonucleus}

The PCV-C group $\left(2.30 \mu \mathrm{m}^{2} \pm 0.80 \mu \mathrm{m}^{2}\right)$ showed a reduction in myonuclei area when compared with the SB group $\left(2.44 \mu \mathrm{m}^{2} \pm 1.05 \mu \mathrm{m}^{2}\right)$, but the difference was not significant $(\mathrm{p}=0,618)$. The PSV group revealed an increase in myonuclei area $\left(2.73 \mu \mathrm{m}^{2} \pm 0.989 \mu \mathrm{m}^{2}\right)$ when compared to the control group (SB), but this difference was not significant $(\mathrm{p}=0.056)$. Significant 
reduction ( $\mathrm{p}=0.002$ ) was observed in myonuclei area of the PCV-C group when compared with the PSV group (Figure 6).

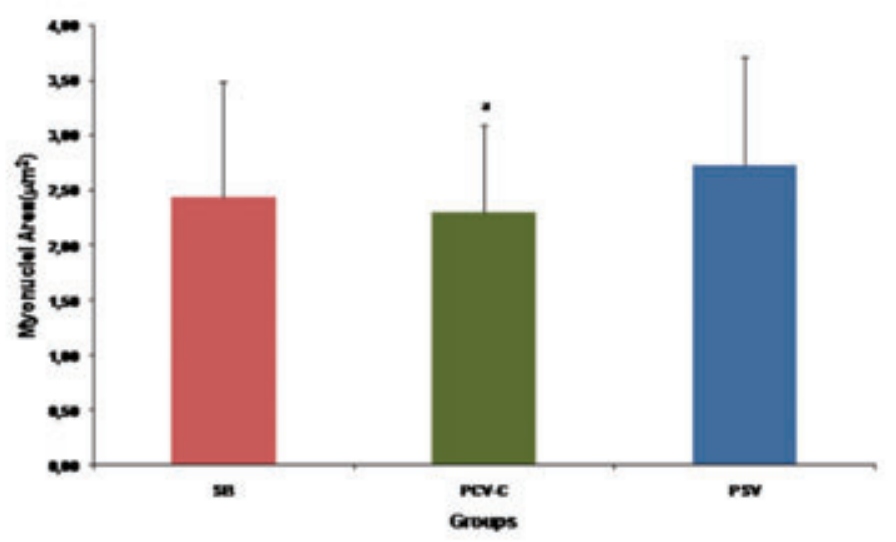

FIGURE 6 - Effects of controlled mechanical ventilation (PCV-C) and Pressure Support Ventilation (PSV) in myonuclei area of rat diaphragm muscle fibers. We observe muscle atrophy in PCV-C group compared to PSV group. Values are represented as mean \pm standard deviation. a $(\mathrm{p}<0.05)$ (ANOVA, followed by Tukey test).

When myonuclei perimeter was analyzed, significant differences between the groups were not observed: PCV-C (7.31m $\pm 1.47 \mu \mathrm{m})$, PSV $(7.49 \mu \mathrm{m} \pm 1.46 \mu \mathrm{m})$ and RE $(7.31 \mu \mathrm{m} \pm 1.68 \mu \mathrm{m})$, with p value of 0.065 (Figure 7).

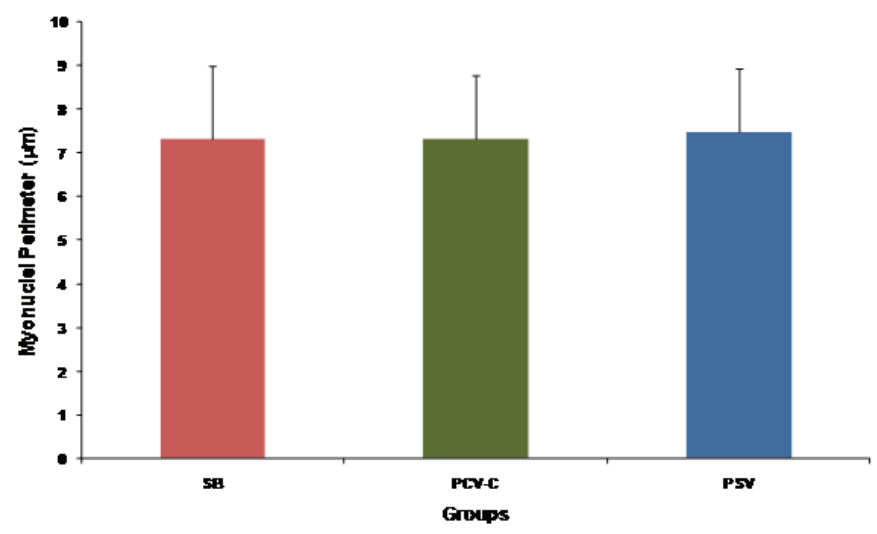

FIGURE 7 - Effects of controlled mechanical ventilation (PCV-C) and Pressure Support Ventilation (PSV) in myonuclei perimeter of rat diaphragm muscle fibers. No differences were observed between groups ( $>00.05$ ). Values are represented as mean \pm standard deviation. (ANOVA, followed by Tukey test).

\section{Discussion}

The major finding of this study, which is the second to compare the PSV mode with the CMV mode, is that, unlike the CMV, the PSV mode seems to attenuate diaphragmatic muscle disuse atrophy due to ventilatory support. This ventilatorinduced diaphragmatic dysfunction (VIDD), analyzed in many studies, may be due to: muscle disuse atrophy, reduced protein synthesis, increased proteolytic activity, oxidative stress, intrinsic abnormalities (ultrastructural level) of muscle fibers, problems with the excitation-contraction coupling and myonuclear $\operatorname{loss}^{2,7,8,12,16,23,24}$.

\section{Analysis of experimental design}

Animal model was chosen to investigate the effects of mechanical ventilation (MV) because of the invasive nature of obtaining diaphragmatic biopsy in humans. Our considerations to choosing animal models involve pragmatic factors (animal size and cost) and the extrapolation of animal models to humans. In relation to pragmatic factors, rat is a relatively cheap model to study the effects of MV, and does not impose any technical difficulties during tracheostomy. Regarding the applicability in humans, rat is an excellent model to investigate diaphragm muscle, because both human and rat diaphragms are similar in anatomy, muscle fiber types and function ${ }^{25,26}$.

To investigate the effects of MV on diaphragm, controlled mechanical ventilation (CMV) was chosen for two reasons. First, this mode has the advantage of producing rapid muscle atrophy ${ }^{12}$. Second, although many patients receive assisted MV, i.e., with diaphragmatic participation, CMV has clinical relevance because this mode is used in adult patients on many circumstances (for ex: drugs overdose, spinal cord injuries, surgeries, etc). It is also well-recognized in some pediatric situations ${ }^{27}$. Pressure support ventilation (PSV) was chosen because literature has only one study investigating the attenuation of protein catabolic effects by using this ventilation mode ${ }^{28}$. This study analyzes diaphragmatic muscle atrophy and the PSV mode seems to preserve diaphragmatic muscle activity when compared with the CMV mode.

In this investigation, all groups received similar doses of anesthetics and sedatives during the experimental period. Animals did not receive anesthetic doses in a continuous form or neuromuscular blockers, like in other studies ${ }^{6,10}$. Barbiturates and neuromuscular blockers have deleterious effects in skeletal muscle function ${ }^{29}$. When applied on an intermittent manner, nevertheless, they do not contribute to $\operatorname{VIDD}^{28}$.

During the experimental period of the PCV-C group, diaphragmatic electromyography was not used in our investigation, as seen in other studies about VIDD ${ }^{4}$. The objective of passive ventilation maybe could not be achieved, and it is possible that animal-ventilator asynchrony could have caused eccentric contractions, resulting in muscle lesion. The animals in our study, however, were monitored by flow and airway pressure waves. Alterations in airway pressure and flow waves suggest 
inspiratory efforts during MV, and have been show to coincide with electromyographic analysis ${ }^{30}$. Uniform airway pressure and flow waves analyzed by the ventilator display, together with the consistence of the respiratory frequency set by the investigator, indicate that passive ventilation was in fact achieved. Occasionally, moments of diaphragmatic activity were observed, but were suppressed by adjusts in peak pressure, to increase tidal volume and consequently depress the respiratory center.

In the present study sodium bicarbonate was not administered to prevent metabolic acidosis. Metabolic acidosis can potentially influence diaphragmatic contractility ${ }^{31,32}$. However, a study demonstrated no decrease in diaphragm strength when $\mathrm{pH}>6,8^{33}$. In this study, before each animal sacrifice, their arterial blood gas was analyzed, and all animals showed $\mathrm{pH}>7.1$.

\section{Muscle atrophy}

During MV, the diaphragm is intermittently and repetitively shortened by cyclical lung inflation ${ }^{34}$. Therefore, changes in the respiratory rate and tidal volume applied during mechanical ventilation will necessarily alter the speed and extent of diaphragmatic shortening. The use of PEEP, on the other hand, will lead to baseline diaphragm shortening at functional residual capacity. It has long been known that the adverse effects of disuse on limb muscle structure are exacerbated by muscle shortening ${ }^{35}$. In addition, maintaining skeletal muscles (including the diaphragm) in a shortened position causes a loss of sarcomeres in series ${ }^{36,37}$. Interestingly, two studies that employed PEEP found that CMV for 48 hours or more resulted in significantly decreased diaphragm muscle optimal length, a finding that strongly suggests the occurrence of such sarcomere loss ${ }^{10,11}$. We applied a PEEP of $5 \mathrm{cmH} 2 \mathrm{O}$ in our study because, in pilot study, rats experimented ventilator asynchrony and suffered acute lung edema when values below that were used. Differences in myosin isoform expression patterns and the degree of atrophy observed among certain studies (in our study as well) may also be at least partly related to the levels of diaphragmatic shortening imposed by the specific ventilator settings applied in these investigations, especially by PEEP.

Controlled mechanical ventilation induces diaphragm muscle atrophy ${ }^{10-13}$. VIDD develops rapidly, as early as $12 \mathrm{~h}$ after the institution of $\mathrm{CMV}^{17}$, and is more pronounced in the diaphragm, which atrophies earlier than the peripheral skeletal muscles that are also inactive during $\mathrm{CMV}^{10-12}$. CMV, in our study, resulted in diaphragm muscle atrophy in only 6 hours of MV, which is a period shorter than seen on other studies.

Although reductions in force-generating capacity found after CMV cannot be attributed only to muscle atrophy, diaphragmatic loss alters maximum force generation in vivo. In addition, the susceptibility of diaphragmatic fatigue in vivo is inversely proportional to maximum force ${ }^{38}$, indicating that diaphragmatic atrophy will increase the risk of diaphragmatic fatigue once spontaneous breathing is assumed again (for instance, with two mechanical ventilation weaning trials ${ }^{39}$ ). Reduction in diaphragm muscle mass and/or atrophy of muscle fibers after CMV were observed in our study. In general, disuse atrophy can be a result of decreased protein synthesis ${ }^{40}$, increased proteolysis ${ }^{41}$, or both. Only in 6 hours of CMV, rats underwent an in vivo reduction in the protein synthesis rate of all muscle proteins by $30 \%$ and in the myosin heavy chain protein rate by $65 \%$, both persisting during 18 hours of $\mathrm{CMV}^{42}$. In addition, 24 hours of CMV suppressed the levels of IGF-1 (insulin-growth factor) mRNA, which stimulates protein synthesis ${ }^{3}$. CMV, therefore, decreases protein synthesis in diaphragm muscle.

An increase in proteolysis in animals diaphragm submitted to 18 hours of CMV has already been studied ${ }^{12}$. All mammalian cells proteases systems (lysossomal proteases, calpains, caspases and proteasome system ${ }^{43}$ ) are activated after the onset of $\mathrm{CMV}^{7,12,44}$, which is one more cause of the muscle fibers atrophy in PCV-C group observed in our study.

The decrease in area and minor diameter of muscle fibers observed in this study in the PCV-C group were not accompanied by reduction in area and perimeter of myonuclei when compared with the control group (SB). Skeletal muscle cells are multinucleated and, theoretically, a single myonucleus can supply the necessary gene expression for a determined area of cytoplasm, a relationship called myonuclear domain ${ }^{17}$. Literature demonstrates a decreased volume of the cytoplasm (atrophy), which is accompanied by a decreased number of myonuclei, not analyzed in our study, but resulting in constant myonuclear domain ${ }^{7}$.That decrease in myonuclear content is mediated by an increase in caspase-3-dependent apoptosis, which was evident after only 6 hours of $\mathrm{CMV}^{7}$. Both apoptosis and atrophy were attenuated with caspase-3 inhibition. It is yet uncertain if assisted modes of mechanical ventilation, like the PSV mode, used in our study, could attenuate these deleterious effects of ventilatory support (muscle fiber atrophy and decreased myonuclei number).

Our study demonstrated that the PSV mode attenuated muscle fiber atrophy of diaphragm in rats. Moreover, in contrast with the PCV-C group, the PSV mode did not show a decrease in area and perimeter of myonuclei when compared to control (SB). Interestingly, the PSV group demonstrated an increase in area and perimeter of myonuclei when compared to the SB group, although this difference was not significant. Also, significant difference was 
observed in myonuclear area in the PCV-C group when compared with the PSV group. These differences in muscle fiber atrophy can be due to differences in the type of muscle lesion caused by the CMV and the PSV modes. In fact, like peripheral skeletal muscle models, during PSV, diaphragm undergoes a type of exercise in which there is an increase in respiratory activity (in comparison to the CMV) $)^{45-47}$. This exercise could protect diaphragm from modifications related to muscular inactivity caused by CMV. During CMV, there is a complete absence of neural activation and diaphragm mechanical activity ${ }^{2,4}$, and a passive shortening of this muscle during lungs inflation ${ }^{34,36}$. This trauma has been implicated in the origin of VIDD ${ }^{12,42}$, particularly during sarcomere injury ${ }^{36,37}$ and during decreased force-generating capacity of diaphragm ${ }^{8,11}$.

\section{Conclusions}

The pressure support ventilation, in a few hours (six), seems to be capable of attenuating the deleterious effects observed when controlled mechanical ventilation is used, related to muscle fiber atrophy. We collected left diaphragm for further biochemical studies to correlate with the findings of this study and maybe suggest, with better scientific support, that the PSV mode can be an alternative way of limiting muscle atrophy and diaphragmatic dysfunction.

\section{References}

1. Levine S, Nguyen T, Taylor N, Friscia ME, Budak MT, Rothenberg P, Zhu J, Sachdeva R, Sonnad S, Kaiser LR, Rubinstein NA, Powers SK, Shrager JB. Rapid disuse atrophy of diaphragm fibers in mechanically ventilated humans. N Engl J Med. 2008;358:1327-35

2. Powers SK, Shanely RA, Coombes JS, Koesterer TJ, McKenzie M, Van Gammeren D, Cicale M, Dodd SL. Mechanical ventilation results in progressive contractile dysfunction in the diaphragm. J Appl Physiol. 2002;92:1851-8.

3. Gayan-Ramirez G, de Paepe K, Cadot P, Decramer M. Detrimental effects of short-term mechanical ventilation on diaphragm function and IGF-I mRNA in rats. Intensive Care Med. 2003;29:825-33.

4. Sassoon CSH, Caiozzo VJ, Manka A, Sieck GC. Altered diaphragm contractile properties with controlled mechanical ventilation. J Appl Physiol. 2002;92:2585-95.

5. Radell PJ, Remahl S, Nichols DG, Eriksson LI. Effects of prolonged mechanical ventilation and inactivitiy on piglet diaphragm function. Intensive Care Med. 2002;28:358-64.

6. Anzueto A, Peters JI, Tobin MJ, De Los Santos R, Seidenfeld JJ, Moore G, Cox WJ, Coalson JJ. Effects of prolonged controlled mechanical ventilation on diaphragmatic function in healthy adult baboons. Crit Care Med. 1997;25:1187-90.

7. McClung JM, Kavazis AN, Deruisseau KC, Falk DJ, Deering MA, Lee Y, Sugiura T, Powers SK. Caspase-3 regulation of diaphragm myonuclear domain during mechanical ventilation induced atrophy. Am J Respir Crit Care Med. 2007;175:150-9.

8. Vassilakopoulos T, Petrof BJ. Ventilator-induced diaphragmatic dysfunction. Am J Respir Crit Care Med. 2004;169:336-41.
9. Lemaire F. Difficult weaning. Intensive Care Med 1993;19(Suppl 2):S69-73.

10. Le Bourdelles G, Viires N, Boczkowski J, Seta N, Pavlovic D, Aubier M. Effects of mechanical ventilation on diaphragmatic contractile properties in rats. Am J Respir Crit Care Med. 1994;149:1539-44.

11. Yang L, Luo J, Boudon J, Lin M, Gottfried SB, Petrof BJ. Controlled mechanical ventilation leads to remodeling of the rat diaphragm. Am J Respir Crit Care Med. 2002;166:1135-40.

12. Shanely RA, Zergeroglu MA, Lennon SL, Sugiura T, Yimlamai T, Enns D, Belcastro A, Powers SK. Mechanical ventilationinduced diaphragmatic atrophy is associated with oxidative injury and increased proteolytic activity. Am J Respir Crit Care Med. 2002;166:1369-74.

13. Capdevila X, Lopez S, Bernard N, Rabischong E, Ramonatxo M, Martinazzo G, Prefaut C. Effects of controlled mechanical ventilation on respiratory muscle contractile properties in rabbits. Intensive Care Med. 2003;29:103-10.

14. Zergeroglu MA, McKenzie MJ, Shanely RA, VanGammeren D, DeRuisseau KC, Powers SKl. Mechanical ventilation-induced oxidative stress in the diaphragm. J Appl Physiol. 2003;95:1116-24.

15. Racz GZ, Gayan-Ramirez G, Testelmans D, Cadot P, De Paepe K, Zador E, Wuytack F, Decramer M. Early changes in rat diaphragm biology with mechanical ventilation. Am J Respir Crit Care Med. 2003;168:297-304.

16. Sassoon CSH, Zhu E, Caiozzo VJ. Assist-control mechanical ventilation attenuates ventilator-induced diaphragmatic dysfunction. Am J Respir Crit Care Med. 2004;170:626-32.

17. Allen DL, Roy RR, Edgerton VR. Myonuclear domains in muscle adaptation and disease. Muscle Nerve. 1999;22:1350-60.

18. Ayas NT, McCool FD, Gore R, Lieberman SL, Brown R. Prevention of human diaphragm atrophy with short periods of electrical stimulation. Am J Respir Crit Care Med. 1999;159:2018-20.

19. Betters JL, Criswell DS, Shanely RA, Van Gammeren D, Falk D, Deruisseau KC, Deering M, Yimlamai T, Powers SK. Trolox attenuates mechanical ventilation-induced diaphragmatic dysfunction and proteolysis. Am J Respir Crit Care Med. 2004;170:1179-84.

20. Jolliet P, Tassaux D. Clinical review: patient-ventilator interaction in chronic obstructive pulmonary disease. Crit Care. 2006;10:236.

21. Brander L, Slutsky AS. Assisted spontaneous breathing during early acute lung injury. Crit Care 2006;10:102.

22. Conti G, Arcangeli A, Antonelli M, Cavaliere F, Costa R, Simeoni F, Proietti R. Sedation with sufentanil in patients receiving pressure support ventilation has no effects on respiration: a pilot study. Can J Anaesth. 2004;51:494-9.

23. Jonghe BD, Bastuji-Garin S, Durand MC, Malissin I, Rodrigues P, Cerf C, Outin H, Sharshar T. Respiratory weakness is associated with limb weakness and delayed weaning in critical illness. Crit Care Med. 2007;35(9):2007-15.

24. Nilsestuen JO, Hargett KD. Using ventilator graphics to identify patient-ventilator asynchrony. Respir Care. 2005;50(2):202-34.

25. Mizuno M. Human respiratory muscles: fibre morphology and capillary supply. Eur Respir J. 1991;4:587-601.

26. Powers SK, Demirel HA, Coombes JS, Fletcher L, Calliaud C, Vrabas I, Prezant D. Myosin phenotype and bioenergetic characteristics of rat respiratory muscles. Med Sci Sports Exerc. 1997;29:1573-9.

27. Hess D, Kacmarek RM. Essentials of mechanical ventilation. New York: McGraw-Hill, Health Professions Division; 1996.

28. Futir E, Constantin JE, Combaret L, Mosoni L, Roszyk L, Sapin V, Attaix D, Jung B, Jaber S, Bazin JE. Pressure support ventilation attenuates ventilator-induced protein modifications in the diaphragm. Critical Care. 2008;12:R116.

29. Giostra E, Magistris M, Pizzolato G, Cox J, Chevrolet J. 
Neuromuscular disorder in intensive care unit patients treated with pancuronium bromide: occurrence in a cluster group of seven patients and two sporadic cases, with electrophysiologic and histologic examination. Chest. 1994;106:210-20.

30. Fernandez R, Mendez M, Younes M. Effect of ventilator flow rate on respiratory timing in normal humans. Am J Respir Crit Care Med. 1999;159:710-9.

31. Fitzgerald RS, Hauer MC, Bierkamper GG, Raff H. Responses in in vitro rat diaphragm to changes in acid-base environment. J Appl Physiol. 1984;57:1202-10.

32. Howell S, Fitzgerald RS, Roussos C. Effects of uncompensated and compensated metabolic acidosis on canine diaphragm. J Appl Physiol. 1985;59:1376-82.

33. Coast JR, Shanley RA, Lawler JM, Herb RA. Lactic acidosis and diaphragmatic function in vitro. Am J Respir Crit Care Med. 1995;152:1648-52.

34. Newman S, Road J, Bellemare F, Clozel JP, Lavigne CM, Grassino A. Respiratory muscle length measured by sonomicrometry. J Appl Physiol. 1984;56:753-64.

35. Goldspink DF, Morton AJ, Loughna P, Goldspink G. The effect of hypokinesia and hypodynamia on protein turnover and the growth of four skeletal muscles of the rat. Pflugers Arch. 1986;407:333-40.

36. Williams PE, Goldspink $\mathrm{G}$. The effect of denervation and dystrophy on the adaptation of sarcomere number to the functional length of the muscle in young and adult mice. J Anat. 1976;122:455-65.

37. Farkas GA, Roussos C. Diaphragm in emphysematous hamsters: sarcomere adaptability. J Appl Physiol. 1983;54:1635-40.

38. Bellemare F, Grassino A. Force reserve of the diaphragm in patients with chronic obstructive pulmonary disease. J Appl Physiol. 1983;55:8-15.

39. Vassilakopoulos T, Zakynthinos S, Roussos C. The tensiontime index and the frequency/tidal volume ratio are the major pathophysiologic determinants of weaning failure and success. Am J Respir Crit Care Med. 1998;158:378-85.

40. Ku Z, Yang J, Menon V, Thomason DB. Decreased polysomal HSP70 may slow polypeptide elongation during skeletal muscle atrophy. Am J Physiol. 1995;268:1369-74.

41. Bodine SC, Latres E, Baumhueter S, Lai VK, Nunez L, Clarke BA, Poueymirou WT, Panaro FJ, Na E, Dharmarajan K, Pan ZQ, Valenzuela DM, Dechiara TM, Stitt TN, Yancopoulos GD, Glass DJ. Identification of ubiquitin ligases required for skeletal muscle atrophy. Science. 2001;294:1704-8.

42. Shanely RA, Van GD, Deruisseau KC, Zergeroglu AM, McKenzie MJ, Yarasheski KE, Powers SK. Mechanical ventilation depresses protein synthesis in the rat diaphragm. Am J Respir Critical Care Med. 2004;170:994-9.

43. Powers SK, Kavazis AN, DeRuisseau KC. Mechanisms of disuse muscle atrophy: role of oxidative stress. Am J Physiol Regul Integr Comp Physiol. 2005;288:R337-44.

44. Maes K, Testelmans D, Powers S, Decramer M, Gayan-Ramirez G. Leupeptin inhibits ventilator-induced diaphragm dysfunction in rats. Am J Respir Crit Care Med. 2007;175:1134-8.

45. Ji LL, Stratman FW, Lardy HA. Enzymatic down regulation with exercise in rat skeletal muscle. Arch Biochem Biophys. 1988;263:137-49.

46. Wakshlag JJ, Kallfelz FA, Barr SC, Ordway G, Haley NJ, Flaherty CE, Kelley RL, Altom EK, Lepine AJ, Davenport GM. Effects of exercise on canine skeletal muscle proteolysis: an investigation of the ubiquitin-proteasome pathway and other metabolic markers. Vet Ther. 2002, 3:215-25.

47. Stupka N, Tarnopolsky MA, Yardley NJ, Phillips SM. Cellular adaptation to repeated eccentric exercise-induced muscle damage.

J Appl Physiol. 2001;91:1669-78.

\section{Aknowledgements}

The authors thank Antonio Roberto, chief of Experimental Surgery Department of Federal University of Pernambuco (UFPE) and his employees, for their assistance and Edeones França, for his technical and scientific support. This work was supported by CNPq and PROPESQ/UFPE

\section{Correspondence:}

André de Sá Braga Oliveira

Programa de Pós-Graduação em Patologia (UFPE)

Cidade Universitária, s/n

50670-901 Recife - PE Brasil

Tel.: (55 81)2126-8515

Fax: (55 81)2126-8529

andre.sboliveira@gmail.com

Received: September 21, 2011

Review: November 23, 2011

Accepted: December 20, 2011

Conflict of interest: none

Financial sources: CNPq and PROPESQ/UFPE

${ }^{1}$ Research performed at Laboratory of Experimental Surgery, Federal University of Pernambuco (UFPE), Brazil. 